Revista de Educação e Pesquisa em Contabilidade

Journal of Education and Research in Accounting

Revista de Educación e Investigatión en Contabilidad
REPeC, Brasília, v. 6, n. 3, instruções aos autores, p. 346-348, jul./set. 2012

Disponível online em www.repec.org.br

ISSN 1981-8610

\title{
Instrução aos Autores
}

\section{REGRAS PARA SUBMISSÃO DE ARTIGOS}

Para submissão de artigos à Revista de Educação e Pesquisa em Contabilidade - REPeC, recomenda-se que os autores verifiquem a conformidade com as normas da ABNT e com os critérios da revista. Serão rejeitadas as submissões que não estiverem de acordo com as normas.

Os artigos devem conter deve ter entre 5.000 e 8.000 palavras, incluindo quadros, tabelas, ilustrações, notas, referências bibliográficas. Serão permitidos, no máximo, 5 (cinco) autores por artigo. Os artigos apresentados em congressos internacionais devem ser enviados no idioma do congresso, se espanhol ou inglês, observando os seguintes elementos:

- $\quad$ As ilustrações, tais como figuras, quadros e tabelas, devem ser elaboradas segundo a norma da ABNT (NBR 14724), sempre em preto e branco, juntamente com legendas, créditos e fonte. Caso haja ilustrações importadas de outros programas, como Excel e Power Point, enviar também o arquivo de origem;

- $\quad$ Não usar expressões como id., ibid., op. cit., loc. cit. e assemelhadas, ou notas de referência e de rodapé; sendo admitidas notas no final do texto;

- Para citações diretas com mais de três linhas, utilizar recuo de $4 \mathrm{~cm}$ da margem esquerda, espaço simples e fonte 10;

- Para citações dentro do texto deve ser utilizado o formato autor/data, por exemplo: Silva e Santos (2009, p. 201); se entre parênteses, apresentar como segue: (SILVA; SANTOS, 2009, p. 201);

\section{FOLHA DE ROSTO}

Título do trabalho em português, inglês e espanhol, nome(s) do(s) autor(es), titulação do(s) autor(es) que o(s) qualifica na área de conhecimento do artigo, vínculo institucional do(s) autor(es), endereço completo, incluindo telefone e e-mail. A folha de rosto deve ser anexada como documento suplementar e conter:

- O título, o resumo e as palavras-chave devem ser enviados em português e inglês, integrando o artigo. O resumo deve ter entre 150 e 250 palavras, seguido de 3 a 5 palavras-chave.

- Abstract (resumo em inglês), obedecendo às mesmas regras do resumo, seguido de três a cinco keywords;

- $\quad$ Resumen (resumo em espanhol), obedecendo às mesmas regras do resumo, seguido de três a cinco palabras clave; 


\section{DESENVOLVIMENTO DO TRABALHO}

- Seção de introdução, contendo a apresentação e contextualização do problema de pesquisa e formulação dos objetivos;

- Seção de fundamentação teórica;

- Seção de procedimentos metodológicos;

- S Seção de análise ou discussão dos resultados;

- Seção de conclusões ou considerações finais.

\section{REFERÊNCIAS}

As referências limitam-se às citadas no trabalho. As referências devem ser listadas no final do texto, em ordem alfabética, fonte 10, alinhadas à esquerda e com espaçamento simples, separadas com espaço de 6 pts entre si, de acordo com a NBR 6023 revisada, conforme os exemplos a seguir:

\section{Livros:}

OHLSON, James; GAO, Zhan. O lucro, seu crescimento e o valor da empresa. São Paulo: Atlas, 2008.

\section{Capítulos de livros:}

GUERREIRO, Reinaldo. Mensuração do resultado econômico. In: CATELLI, Armando (Coord.). Controladoria: uma abordagem da gestão econômica - GECON. São Paulo: Atlas,1999. pp. 81-102.

\section{Artigos de periódicos:}

SALOTTI, Bruno Meirelles; YAMAMOTO, Marina Mitiyo. Divulgação da Demonstração dos fluxos de caixa no mercado de capitais brasileiro. Revista Contabilidade \& Finanças - USP, São Paulo, n. 48, p. 37-49, set./dez. 2008.

\section{Artigo on line (retirado da internet):}

WATTS, Ross. A proposal for Research on Conservantism. For discussion at the AAA Convention, San Francisco, CAAugust, 1993. Disponible en: < http://papers.ssrn.com/sol3/papers.cfm?abstract_ id $=6044>$. Acesso em: 02.05.2008

\section{Artigos de anais:}

BRUNI, Adriano Leal; GAMA, Alex; FAMÁ, Rubens.; FIRMINO, Adilson. O anúncio da distribuição de dividendos e seu efeito sobre os preços das ações: um estudo empírico no Brasil. In: CONGRESSO USP DE CONTROLADORIA E CONTABILIDADE, 3, 2003, São Paulo/SP. Anais... São Paulo: USP, 2003. CD-ROM.

\section{Dissertações e teses:}

BUENO, Artur Franco. Análise empírica do dividend yeld das ações brasileiras. 2000. 115 f. Dissertação (Mestrado em Controladoria e Contabilidade) - Curso de Pós-Graduação em Controladoria e Contabilidade, Faculdade de Economia, Administração e Contabilidade. Universidade de São Paulo, São Paulo, 2000. 


\section{repec}

\section{CHECKLIST PARA SUBMISSÃO}

Como parte do processo de submissão, os autores devem verificar a conformidade em relação a todos os itens listados a seguir. Serão rejeitadas as submissões que não estiverem de acordo com as normas.

1. Folha de rosto com os seguintes dados: título do trabalho em português, inglês e espanhol, nome(s) do(s) autor(es), titulação do(s) autor(es) que o(s) qualifica na área de conhecimento do artigo, vínculo institucional do(s) autor(es), endereço completo, incluindo telefone e e-mail. A folha de rosto deverá ser anexada como documento suplementar.

2. Resumo no idioma do texto contendo entre 150 e 250 palavras, em um único parágrafo, espaço simples entre linhas, seguido de três a cinco palavras-chave.

3. Abstract (resumo em inglês), obedecendo às mesmas regras do resumo, seguido de três a cinco keywords.

4. Resumen (resumo em espanhol), obedecendo às mesmas regras do resumo, seguido de três a cinco palabras clave;

5. O arquivo para submissão, separado da folha de rosto, deve estar em formato Microsoft Word, (desde que não ultrapasse $2 \mathrm{MB}$ ) e sem proteção em "propriedades".

6. Formato A4 (210 x 297mm), fonte Times New Roman, tamanho 12, espaço simples entre linhas, margens superior e esquerda de $3 \mathrm{~cm}$, inferior e direita de $2 \mathrm{~cm}$.

7. As páginas dos artigos devem ser numeradas no canto superior direito.

8. As ilustrações e tabelas em fonte Times New Roman, tamanho 10, acompanhados de cabeçalho, fonte dos dados e legendas quando necessárias, de maneira que permita compreender o significado dos dados reunidos, sem necessidade de referência ao texto.

9. As citações devem acompanhar o critério autor/data, por exemplo, Dimaggio e Powell (1991), (DIMAGGIO e POWELL, 1991) ou Dimaggio e Powell (1991, p.34), conforme o caso.

10. Para citações diretas é indispensável a indicação da página. Citações com até três linhas devem vir no próprio texto e entre aspas, com mais de três linhas devem ser destacadas com recuo de quatro centímetros da margem esquerda, em tamanho 10, sem aspas, conforme a NBR 10520:2002 da ABNT.

11. Não serão aceitas notas de rodapé, à exceção das credenciais dos autores e agradecimentos às agências de fomento.

12. Anexos e apêndices somente devem ser empregados no caso de listas, estatísticas e outros elementos de suporte indispensáveis para o entendimento do texto. 